\title{
Foreign Direct Investment And Air Pollution: Granger Causality Analysis
}

\author{
Vinod Kumar ${ }^{1}$, Rakesh Chander ${ }^{2}$ \\ ${ }^{1,2}$ (Research Scholar, Department of Commerce, Kurukshetra University, Kurukshetra, India)
}

\begin{abstract}
This paper seeks to examine the relationship between foreign direct investments (FDI) inflow, and CO2 emissionin Indiafrom last three decade (1981 to 2011). This study provides a better understanding offoreign investment while maintaining a sustainable development. In order to achieve this task, this paper tests whether or not FDI inflow has impact on environmental deterioration in particular on air quality. The Unit Root test,Johansen Co-integration test and Granger-causality test has been used to check the causal relationship between foreign direct investments (FDI) inflow and Airpollution. The findings show that FDI has significant andnegative impact on the air quality in India. There are needs to set environmental policy and to monitor progress towards meeting society environmental goals; a reliable information system and database for degradation of environment are needed. Since the paper shows that FDI has negative impact on the air quality, this result is important in framing policy regarding FDI and pollution regulation in India.
\end{abstract}

Keywords:CO2emissions, FDI inflows, granger causality, johansen co-integration, pollution heaven.

\section{INTRODUCTION}

Across the world, there is growing interest and research carried out on sustainable development, particularly with the increasing $\mathrm{CO} 2$ emission level and harms theenvironment. According to the 2011 data published by World Bank, India ranks fourth in terms of countries' share of carbon dioxide emissions after China, U.S. and Russia [1]. Carbon dioxide emissions are those stemming from the burning of fossil fuels and the manufacture of cement. They include carbon dioxide produced during consumption of solid, liquid, and gas fuels and gas flaring [2]. In this paper $\mathrm{CO} 2$ use as a environmental pollution measure because $\mathrm{CO} 2$ currently represents about 84 percent of all greenhouse gases emitted by human activities, totalling about 30 billion tons in a year and Most of this comes from burning fossil fuels for electricity, transportation, and industrial processes contribute heavily [3]. CO2emissions arenowbelievedtobetheprimarygreenhousegas responsiblefortheproblemofglobalwarming [4]. The combustion-based production of $\mathrm{CO} 2$ has evolved into a major environmental challenge that extends beyond national borders and the issue has become as politically charged as it is technologically demanding [5].The environmental impact of FDI inflow is a continuing debate issue in developing economies. This debate assumes special importance in view of recent changes in the composition and direction of foreign direct investment (FDI), and liberalization of government policies towards FDI in developing economies.

In this paper pollution haven hypothesis are examined in context of India for the period 1981 to 2011. Pollution haven hypothesis claims the possibility that foreign investment could sensitive to weaker environmental standards. The pollution haven hypothesis has two empirical consequences, namely: FDI outflow in developed countries is positively correlated with environmental policy strictness and pollution in developing countries is positively linked to FDI inflow [6].According to World Bank indicator the total FDI inflow increased 91.92 U.S.\$ billion to 36498 U.S. \$ billion with 0.57 average growth rate per year in last three decades due to adopting open globalized economy policy. Also $\mathrm{CO} 2$ emission shows the upward trend from 0.53 to 1.66 metric ton per capita. So regulating the FDI inflow is becoming necessary for bringing down the level of $\mathrm{CO} 2$. In order to check the relationship between in these two main indicators granger causality and Johansen Cointegration Test has been adopted. The findings of the study show that there is a strong relationship between FDI inflow andCO2 emission and result support the population haven hypothesis in Indian context. 


\section{REVIEW OF LITERATURE}

Across the world there have been an increasing number of empirical studies which focus on the effect of FDI on environmental pollution. The results, however, have been mixed. Empirical studies have not been able to generate consistent evidence for significant and negative pollution effects from FDI. While many researchers found significant and negative pollution effect from FDI, some others found no or statistically insignificant pollution effects.In their study, (Hoffmann, Lee, Ramasamy, \& Yeung, 2005) studied the Granger causality tests on the relationship between FDI and pollution across 112 countries and found thatin low-income countries, CO2-levels Granger cause inward FDI flows. In middle-income countries, inward FDIGranger causesCO2emissionsand for high-income countries no Granger causality.Developing countries are also interest of environmental degradation [7].(Ajide,2010)investigatedthe causal relationship among FDI, economic growth and environment in Nigeria.Itwasdescribed none existence of a long run relationship between FDI and growth, and between $\mathrm{CO} 2$ and FDI inflows there exists a long run causal relationship.A number of study provided evidence that FDI has a positive impact on air quality [8].(Liang, 2006) inspected the relationship between the scale of foreign direct investment and local air pollution in China. Using a panel data covering more than 200 major cities evidence found that foreign investment has beneficial effect on local environment [9].(Kirkulak, Qiu, Yin, Kirkulak, \& Qiu, 2011) studied the impact of foreign direct investments (FDI) on air pollution in China. It was showed that FDI has negative but not significant impact on air quality. Air pollution proposing that air pollution decreases by the volume of foreign investment [10]. Some studies found evidence supporting the negative impact of FDI on air pollution.(Hitam \& Borhan, 2012)observed the relationship between FDI, GDP growth and pollution in Malaysia. It was explained thatsustained growth of foreign direct investment is one of the importantcauses of environmentaldegradation [11].(Kheder, 2010) measured relationship between foreign direct investment, environmental regulation and pollution, in France. The study found negative impact of environmental regulation on FDI location [12].(Avazalipour, Zandi, Saberi, \& Hakimipour, 2013) claimed that there is significant relationship between FDI and pollution.Foreign Direct Investment causes environmental disturbances in Non OECD countries [13].(Acharyya, 2009) found a statistically significant long run positive, but marginal, impact of FDI inflow on GDP growth the long run growth impact of FDI inflow on CO2 emissions is quite large [14].(Vadlamannati, $\tilde{A}, \&$ Pin, 2009)revealed that higher degree of economic and financial development decreases the environmental degradation and suggested that financial liberalization and openness are essential factors for the $\mathrm{CO} 2$ reduction [15].

\section{OBJeCtives ANd Methodology}

\subsection{OBJECTIVES OF THE STUDY}

The following are the objectives of the study undertaken:

$>$ To analyzed the trend of FDI inflow and $\mathrm{CO} 2$ emission in India.

$>$ To examine if the degree of FDI inflow has a systematic relationship with the level of $\mathrm{CO} 2$ emissions in India.

\subsection{HYPOTHESES}

$>\mathrm{H}_{1}$ FDI does not Granger-cause air pollution or vice versa.

$>\mathrm{H}_{2}$ There is no co-integration between FDI and $\mathrm{CO} 2$ emissions.

\subsection{DATA AND VARIABLE FORM}

The present study used annual FDI inflow measured in US \$ at current prices and current exchange rates.CO2 emission has taken as a proxy variable for measure of environmental pollution quality.The unit that measures $\mathrm{CO} 2$ emission is $\mathrm{kt} \mathrm{CO} 2$ emissions respectively. TheCO2emission and annual FDIinflows datasetswere collectedfrom theWorld Bank Indicator database.Thedata have been taken for 30 yearsperiod of 1981 to 2011. 


\subsection{TOOL USED}

Unit root test,Johansen Co-integration and Granger causality test are used for analyzing the data. Firstly descriptive statistics such as mean, median, standard deviation, and kurtosis has been calculated for both time series.To test stationarity of the time series Unit root test (Augmented Dickey-Fuller) has been used.For check co-integration between the series Johansen Co-integration Testhas been apply and for determiningcause effect relationship between FDI inflow and $\mathrm{CO} 2$ emission granger causality test has been used.

\section{FINDINGS AND DISCUSSION}

4.1 In this section, the results of descriptive statistics have been present for both time series.

TABLE I: Descriptive Statistics for the FDI inflow and CO2 emission

\begin{tabular}{|l|l|l|}
\hline Descriptive Statistics & $\begin{array}{l}\text { FDI inflow } \\
\text { (US \$ in millions) }\end{array}$ & $\begin{array}{l}\text { CO2 emission } \\
\text { (Metric tons per capita.) }\end{array}$ \\
\hline Mean & 7619.83 & 1.01 \\
\hline Median & 2168.59 & 1.02 \\
\hline Maximum & 43406.28 & 1.66 \\
\hline Minimum & 5.64 & 0.53 \\
\hline Std. dev. & 12498.42 & 0.33 \\
\hline Skewness & 1.74 & 0.38 \\
\hline Kurtosis & 4.60 & 2.28 \\
\hline
\end{tabular}

Source: Computed from www.wordbank.com/data/indicater

Table shows that mean is 7619.83 and 1.01 for FDI inflow and CO2 emissionrespectively. Standard deviation shows the extent ofvariability in the series which is 12498.42 for FDI inflow series and 0.33 for CO2 emission time series. Skewness shows the distribution of the data. Data is positively skewed in both series andKurtosis(which refers to the degree of flatness at the top of the distribution) of the FDI inflow series is more than 3 so series is peaked and in case of $\mathrm{CO} 2$ series the kurtosis value is less than 3 the distribution of $\mathrm{CO} 2$ series is flat.

\subsection{Unit RoOt TEST RESUlTS}

Before going for rigorous econometrics analysis we test properties of both time series whether they are stationarity or not. If there is shocks present in the series and this will be non-stationary time series. Therefore, to identify the shock present in our data we need to apply Augmented Dickey Fuller unit root tests (ADF Test).As result present in table 2, the Augmented Dickey-Fuller unit root tests with trend and intercept which are selected to test both series. The null hypothesis supposed that the data series has a unit root.

TABLE II. Unit Root Test Results for the FDI inflow and CO2 emission

\begin{tabular}{|l|l|l|l|l|l|}
\hline \multirow{2}{*}{ Variable } & \multirow{2}{*}{$\begin{array}{c}\text { ADF } \\
\text { t value }\end{array}$} & \multicolumn{2}{|l|}{$\begin{array}{l}\text { Critical value* } \\
\text { At significant level }\end{array}$} & \multirow{2}{*}{ p value } & \multirow{2}{*}{ Null Hypothesis** } \\
\cline { 3 - 4 } & & $1 \%$ & $5 \%$ & $10 \%$ & \\
\hline
\end{tabular}


IOSR Journal of Business and Management (IOSR-JBM)

e-ISSN: 2278-487X, p-ISSN: 2319-7668

\begin{tabular}{|l|l|l|l|l|l|l|}
\hline $\begin{array}{l}\text { FDI } \\
\text { (At level) }\end{array}$ & 3.8227 & -4.3560 & -3.5950 & -3.233 & 1.000 & Accepted \\
\hline $\begin{array}{l}\text { CO2 } \\
\text { (At level) }\end{array}$ & -4.0821 & -4.3743 & -3.6032 & -3.2380 & 0.0187 & Rejected \\
\hline FDI ${ }^{* * *}$ & -0.8759 & $-4 . .3743$ & -3.6032 & -3.2380 & 0.9434 & Accepted \\
\hline FDI $^{\#}$ & -8.4531 & -4.3743 & -3.6032 & -3.2380 & 0.0013 & Rejected \\
\hline
\end{tabular}

Note: *MacKinnon critical values, ADF Augmented Dickey Fuller Test statistics, **Null Hypothesis: The series has Unit root or non stationarity. *** At first difference.\# At second difference.

The results indicates that for FDI series at level ADF test value is 3.8227 which are greater than critical value at $1 \%, 5 \%$ and $10 \%$ significant level and $\mathrm{p}$ value is 1.000 . So we accept the null hypothesis that FDI series is non stationarity. In case of $\mathrm{CO} 2$ series $\mathrm{ADF}$ test value is -4.0821 which is less than critical value at $5 \%$ and $10 \%$ significant level and $\mathrm{p}$ value is 0.0187 . So we reject the null hypothesis that $\mathrm{CO} 2$ series is non-stationary. FDI series is stationary at second difference as shown in the table the test value of the series is -8.4531 , which is less than critical value at $1 \%, 5 \%$ and $10 \%$ significant level and $\mathrm{p}$ value is 0.0013 . So we reject null hypothesis that series is non-stationary.

4.3 Cointegration Test Results:

To analyze the long-term relationship, the Johansen Cointegration test between the FDI inflow and $\mathrm{CO} 2$ emission for the studyperiodhas been conducted.Two variables will be cointegrated if they have a longterm, or equilibrium relationship between them [16]. The test is applied on the level data. We take null hypothesis that there is Cointegration between the variable.

Table 3: Johansen Co-integration Test betweenFDI inflow and CO2

\begin{tabular}{|l|l|l|l|l|l|l|l|}
\hline \multirow{2}{*}{ Period } & $\begin{array}{l}\text { Hypothesized } \\
\text { No.of CE(S) }\end{array}$ & $\begin{array}{l}\text { Trace } \\
\text { Statistics }\end{array}$ & $\begin{array}{l}\text { Critical } \\
\text { value }\end{array}$ & $\begin{array}{l}\mathbf{P} \\
\text { Value }\end{array}$ & $\begin{array}{l}\text { Max- eigen } \\
\text { Statistics }\end{array}$ & $\begin{array}{l}\text { Critical } \\
\text { value }\end{array}$ & $\begin{array}{l}\mathbf{P} \\
\text { Value }\end{array}$ \\
\hline \multirow{2}{*}{$1981-2011$} & None & 15.4947 & 15.4947 & 0.0281 & 15.9772 & 14.265 & 0.0265 \\
\cline { 2 - 8 } & At most 1 & 1.1538 & 3.8415 & 0.2828 & 1.1538 & 3.8415 & 0.2828 \\
\hline
\end{tabular}

* Significant level at 5\%

As the table show that for the time period 1981 to 2011 in case of null hypothesis thatthere is no Cointegration in equation, the trace value is greater than critical value and p value is 0.0265 which is less than $5 \%$, so we can reject null hypothesis. It is concluded that FDI and CO2 are cointegrated or they move together in long run. The results remain the same (Table 3)as indicated both by trace statistics as well as Maximum Eigenvalue test for the periods.

\subsection{GRanger CAusality Test Result}

Granger (1969) proposed a time-series data based approach in order to determine causality. Granger causality test shows the relationship of precedence among variables. This test will helpful in found the answer whether X cause $\mathrm{Y}$. Y is said to be granger caused by X if X helps in the prediction of $\mathrm{Y}$ [17]. It is applied on thestationary series.So hereit is applied on the after second difference of FDI inflow and CO2 emission at level series which is stationary. We take null hypothesis as FDI doses not granger cause of $\mathrm{CO} 2$ and vice versa. Before apply to this test the optimal lag must be selected because the results are very sensitive to the number of Special Issue - AETM'16 15| Page 
lags used in the analysis. This study adopts Schwartz information criterion (SIC) in which lag 4 is found to be the optimal lag for the total time periods.

TABLE IV. Granger Causality Tests Total period (1981-2011)

\begin{tabular}{|c|c|c|c|c|c|}
\hline & Null Hypothesis & $\begin{array}{l}\text { F } \\
\text { Statistics }\end{array}$ & P value & Result & Relationship \\
\hline $\mathrm{H}_{1}$ & FDI does not Granger Cause CO2 & 6.0263 & 0.0031 & Rejected & \multirow{2}{*}{ Bi-directional } \\
\hline $\mathrm{H}_{2}$ & $\mathrm{CO} 2$ does not Granger Cause FDI & 3.2474 & 0.0395 & Rejected & \\
\hline
\end{tabular}

The Table shows thatfor the $\mathrm{H}_{1}$ the $\mathrm{p}$ value is 0.0031 which is less than 0.05 so we reject the null hypothesis which means FDI inflow Granger CausesCO2 emission. For the $\mathrm{H}_{2}$, p value is 0.0031 which is less than 0.05 so null hypothesis is rejected which means $\mathrm{CO} 2$ emission CausesFDIinflow. So there is causality among the $\mathrm{CO} 2$ emission or FDI inflow and there bi-directionalrelationship existsbetween these two variables.

\section{CONCLUSION AND SUggestion}

In the present research, testing of hypothesis explained that FDI inflow is positively related to the level of pollution.On the basis of gained results from presented research, it suggests that there are need to set environmental policy and to monitor progress towards meeting society environmental goals; a reliable information system and database for degradation of environment. Further the scope of research can be increased up to other types of pollutants and observe FDI effects on those pollutants and compare them. In future comparison can be studiedbetween FDIenvironmental effects in comparison of other countries.During the past three decade, in India FDI become a major source for economic growth. This growth raises a question of whether or not the higher FDI inflow has been returned in the sense of air pollution. So in this study we examine the impact of FDI inflow on air pollution in term of $\mathrm{CO} 2$ emission. The result shows that there is positive relationship between FDI inflow and $\mathrm{CO} 2$ emission. In India there is upward trend in $\mathrm{CO} 2$ emission and FDI both. Pollution haven hypothesis claims that pollution in developing countries is positively linked to FDI inflow. The study reveals the fact that foreign funding companies or units are associated with heavy pollution activities. Hence it can be stated that finding of research has supported pollution haven hypothesis in context India.

\section{REFERENCES}

[1] D. Sanyal, "Green problem: How India fares in Global carbon emissions”, Business Standard, 2015.

[2] "World Development Indicators (WDI)", World Bank, (2011). Data retrieved March 2, 2016, from World Development Indicators Online (WDI).

[3] J. Platt, "CO2 101: Why is carbon dioxide bad?", 2013.

[4] United States Congress, House (n.d.),'Examining the U.N. Intergovernmental Panel on Climate Change process: Hearing before the Committee on Science, Space, and Technology", 2014.

[5] T. Mill, M. Park and D. Ross, "Reductive Sequestration of Carbon Dioxide", 2000, 1-9.

[6] M. A. Aliyu, "Foreign Direct Investment and the Environment: Pollution Haven Hypothesis Revisited", Proc. $8^{\text {th }}$ Annual Conf. on Global Economic, 2005, 1-35.

[7] R. Hoffmann, C.G. Lee, B. Ramasamy and M. Yeung, "FDI and pollution: a granger causality test using panel data", Journal of International Development, 17(3), 2005, 311-317.

[8] Ajide, O. Adeniyi, "FDI and the enviornment indevloping economics: Evidence from nigeria", Enviornmental Research Journal, 4(4) 2010, 291-297.

[9] F. H. Liang, "Does Foreign Direct Investment Harm the Host Country 's Environment ?: Evidence from China, $2006,1-24$.

[10] B. Kirkulak, B. Qiu, W. Yin, B. Kirkulak and B. Qiu, "The impact of FDI on air quality: evidence from China", 2011. 
IOSR Journal of Business and Management (IOSR-JBM)

e-ISSN: 2278-487X, p-ISSN: 2319-7668

[11] M. B. Hitam, and H. B. Borhan, "FDI, Growth and the Environment: Impact on Quality of Life in Malaysia", Procedia - Social and Behavioral Sciences, 50(3), 2012, 33-342.

[12] S. B. Kheder, "French FDI and Pollution Emissions : an Empirical Investigation", 2010, 1-44.

[13] M. S. Avazalipour, F. Zandi, R. Saberi and N. Hakimipour, "The Impact Of Fdi On Environmental Resources In Selected Countries (Non- Oecd), 17, 2013, 111-115.

[14] Acharyya, J. (2009). Fdi, Growth And The Environment: Evidence From India On Co2 Emission During The Last Two Decades. Journal of Economic Development, 34(1), 43-58.

[15] K. C. Vadlamannati, Ã, A. T. and J. Pin, "Does higher economic and financial development lead to environmental degradation: Evidence from BRIC countries", 37, 2009, 246-253.

[16] D. N. Gujarati and D. C. Porter, Essentials of econometrics (1999).

[17] C. Granger, "Investigating Causal Relations by Econometric Models and Cross Spectral Methods.Econometric", 37, 1969, 424-38. 